\title{
Fgfr1 regulates development through the combinatorial use of signaling proteins
}

\author{
J. Richard Brewer, ${ }^{1}$ Andrei Molotkov, ${ }^{1}$ Pierre Mazot, ${ }^{1}$ Renée V. Hoch, ${ }^{2,3}$ and Philippe Soriano ${ }^{1,2}$ \\ ${ }^{1}$ Department of Developmental and Regenerative Biology, Tisch Cancer Institute, Icahn School of Medicine \\ at Mount Sinai, New York, New York 10029, USA; ${ }^{2}$ Division of Basic Sciences, Fred Hutchinson Cancer Research Center, \\ Seattle, Washington 98109, USA
}

\begin{abstract}
Fibroblast growth factor (Fgf) signaling governs multiple processes important in development and disease. Many lines of evidence have implicated Erk1/2 signaling induced through Frs2 as the predominant effector pathway downstream from Fgf receptors (Fgfrs), but these receptors can also signal through other mechanisms. To explore the functional significance of the full range of signaling downstream from Fgfrs in mice, we engineered an allelic series of knock-in point mutations designed to disrupt Fgfr1 signaling functions individually and in combination. Analysis of each mutant indicates that Frs2 binding to Fgfr1 has the most pleiotropic functions in development but also that the receptor uses multiple proteins additively in vivo. In addition to Frs2, Crk proteins and Plc $\gamma$ also contribute to Erk1/2 activation, affecting axis elongation and craniofacial and limb development and providing a biochemical mechanism for additive signaling requirements. Disruption of all known signaling functions diminished Erk1/2 and Plc $\gamma$ activation but did not recapitulate the peri-implantation Fgfr1-null phenotype. This suggests that Erk1/2-independent signaling pathways are functionally important for Fgf signaling in vivo.
\end{abstract}

[Keywords: craniofacial development; gastrulation; MAPK; preimplantation; signaling]

Supplemental material is available for this article.

Received May 2, 2015; revised version accepted August 10, 2015.

Fibroblast growth factor receptors (Fgfrs) are receptor tyrosine kinases (RTKs) that play pleiotropic roles in development and disease (Beenken and Mohammadi 2009). Eighteen Fgf ligands bind to four Fgfrs to regulate diverse cellular processes, including proliferation, migration, and differentiation (Dorey and Amaya 2010; Ornitz and Itoh 2015). Current data suggest that Fgfr1 is first required during gastrulation, and Fgfr1-null mouse embryos show an accumulation of cells at the primitive streak, with an expansion in axial mesoderm and a deficiency of paraxial mesoderm (Deng et al. 1994; Yamaguchi et al. 1994). Further work has shown that $\mathrm{Fgfr}^{-/-}$mutants fail to complete an epithelial-to-mesenchymal transition necessary to form mesoderm (Ciruna et al. 1997; Ciruna and Rossant 2001). Fgfrl is subsequently required for development in numerous contexts, such as the limbs, lungs, skeleton, central nervous system, ears, and palate. Many of these developmental roles are disrupted in human syndromes associated with Fgfr1 mutations, suggesting that these functions are conserved (Ornitz and Itoh 2015).

Ligand binding facilitates receptor activation and initiation of an intracellular signaling cascade. Fgfrl interacts with multiple signaling proteins, including Frs2, Frs3,

\footnotetext{
${ }^{3}$ Present address: PLoS One, San Francisco, CA 94111, USA.

Corresponding author: philippe.soriano@mssm.edu

Article is online at http://www.genesdev.org/cgi/doi/10.1101/gad.264994.

115 .
}

Crk/CrkL, Plc $\gamma$, and Grb14. Many of these signaling proteins serve as adaptors that activate various pathways with the exception of Plc $\gamma$, which functions as a phospholipase. Frs2 binds the juxtamembrane region of Fgfr1 and is tyrosine-phosphorylated by the receptor on multiple residues. Phosphorylated Frs2 binds Grb2-Sos to activate the Ras-Erk1/2 signaling cascade (Kouhara et al. 1997) and associates with Gabl to activate PI3K/Akt (Ong et al. 2001). Multiple lines of evidence implicate Frs2-mediated Erk1/2 activation as the predominant signaling pathway downstream from Fgfrs (Kouhara et al. 1997; Hadari et al. 2001; Gotoh et al. 2004b; Eswarakumar et al. 2005; Lanner and Rossant 2010). Many mouse mutants along this Fgf-Erk1/2 signaling axis die around the time of implantation of the embryo into the uterus, including some predicted null alleles of Fgfr2, Fgf4, Grb2, and Erk2 (Feldman et al. 1995; Arman et al. 1998; Cheng et al. 1998; Hadari et al. 2001; Goldin and Papaioannou 2003; Hatano et al. 2003; Saba-El-Leil et al. 2003). The Fgf-Erk1/2 signaling pathway has been implicated in epiblast and primitive endoderm lineage restriction in the blastocyst (Feldman et al. 1995; Cheng et al. 1998;

(C) 2015 Brewer et al. This article is distributed exclusively by Cold Spring Harbor Laboratory Press for the first six months after the full-issue publication date (see http://genesdev.cshlp.org/site/misc/terms.xhtml). After six months, it is available under a Creative Commons License (Attribution-NonCommercial 4.0 International), as described at http:// creativecommons.org/licenses/by-nc/4.0/. 
Chazaud et al. 2006; Nichols et al. 2009; Yamanaka et al. 2010; Frankenberg et al. 2011; Kang et al. 2013; Morris et al. 2013). Additionally, Fgf signaling promotes embryonic stem (ES) cell differentiation, while inhibition of Erk1/2 or genetic loss of Erk2 maintains pluripotency in ES cells (Kunath et al. 2007; Stavridis et al. 2007; Nichols et al. 2009; Hamilton et al. 2013).

Despite the importance of Frs2-Erk1/2 signaling, not all Fgfr functions can be attributed to this pathway. Mice harboring a deletion of the Fgfr1 juxtamembrane region required for Frs2 and Frs3 binding (Fgfr1 $1^{\triangle F R S}$ allele) die late in development with defects in tail bud, pharyngeal arch (PA), and neural tube development (Hoch and Soriano 2006). Failure of $F g f r 1^{\triangle F R S / \triangle F R S}$ mutants to recapitulate the Fgfr1 ${ }^{-/-}$phenotype suggests that Frs $2 / 3$ is required for only a subset of Fgfr 1 signaling functions. It is therefore important to interrogate the function of Frs2-independent signaling downstream from Fgfr1.

Activated Fgfr1 can recruit several other signaling proteins in vitro (Eswarakumar et al. 2005). Crk adaptor proteins interact with Fgfr1 through phosphorylated Tyr463 in order to mediate cell proliferation via Erk1/2 and Jnk in endothelial cells (Larsson et al. 1999). A similar adaptor protein, CrkL, interacts with Fgfrl and is required for Erk1/2 activation, cardiovascular development, and cell migration in the PAs (Guris et al. 2001; Moon et al. 2006). Plc $\gamma$ interacts with Fgfr1 through phosphorylated Tyr766 and is subsequently activated by tyrosine phosphorylation in vitro (Mohammadi et al. 1991). Activated Plc $\gamma$ hydrolyzes $\mathrm{PIP}_{2}$ in order to regulate $\mathrm{Ca}^{2+}$ levels and $\mathrm{Pkc} \delta$ activity (Mohammadi et al. 1992). Fgfr1-Plc $\gamma$ signaling has been implicated in endocytosis of the receptor in vitro (Sorokin et al. 1994) and negative regulation of signaling in vivo (Partanen et al. 1998). Grb14 is an adaptor protein that binds Tyr766 and Tyr776 (Reilly et al. 2000) in order to inhibit Fgfr1-mediated activation of Plc $\gamma$ (Browaeys-Poly et al. 2010).

To understand the mechanisms through which Fgfr1 elicits pleiotropic functions in vivo, it is critical to elucidate how multiple signaling pathways are coordinated to instruct cellular processes. Studies of other RTKs have supported at least two models of how downstream pathways are used in vivo. Pdgfra, Kit, and Met use pathways modularly; i.e., different signaling pathways are required in distinct contexts (Blume-Jensen et al. 2000; Maina et al. 2001; Klinghoffer et al. 2002; Agosti et al. 2004). In contrast, Pdgfr $\beta$ uses multiple pathways additively such that loss of progressively more signaling pathways results in increasingly severe defects within a single cell lineage (Tallquist et al. 2003).

To understand how Fgfrl signals in vivo, we generated an allelic series designed to disrupt each known signaling function of Fgfr1 individually and in combination. Analysis of these mutants indicates that Frs2 is the most important individual protein that binds to the receptor but also that Fgfrl uses multiple signaling proteins additively in vivo. The model of additive signaling requirements is novel for Fgfrs and demonstrates functional roles for Crk proteins, Plc $\gamma$, and Grb14 downstream from Fgfrs. Biochemical evidence indicates that multiple proteins converge on Erk1/2 and Plc $\gamma$, providing a mechanism for additive signaling requirements. Loss of all known Fgfr1 signaling functions does not phenocopy the $\mathrm{Fgfr}_{\mathrm{H}}^{-/-}$phenotype and diminishes Fgfrl-activated Erk1/2 and Plc $\gamma$ signaling without affecting PI3K/Akt signaling. This suggests that Erk1/2-independent signaling activities are functionally important in Fgfrl signaling.

\section{Results}

\section{An allelic series of Fgfrl knock-in point mutations}

To better understand how Fgfrl signals in vivo, we generated mice in which point mutations were knocked into genomic exons (Fig. 1A; Supplemental Fig. S1). These mutations were engineered in ES cells, and proper targeting events were confirmed by Southern blotting (Supplemental Fig. S1). Two mouse lines were generated from independent ES cell clones for each allele, and phenotypes were confirmed in both lines. 3T3 cells stably expressing triple-Flag-tagged murine Fgfr1 isoform "c" (Fgfr1 ${ }^{\text {-Flag3x }}$ ) cDNAs were generated for each signaling mutant and used to ensure that each amino acid substitution functioned as intended. Coimmunoprecipitation of Fgfr1 with Plc $\gamma$, CrkL, and Frs2 (Fig. 1B) confirmed that these amino acid substitutions functioned to disrupt each protein com-
A

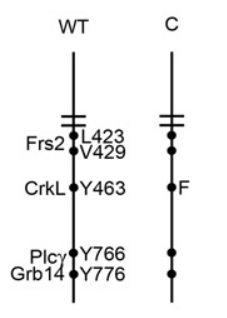

B

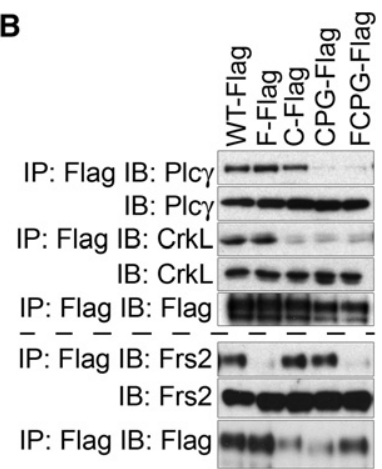

Figure 1. An allelic series of Fgfr1 knock-in point mutations. (A) Schematic representation of the allelic series generated for this study. Protein complexes and critical residues are shown at the left and right of the wild-type (WT) receptor, respectively. Amino acid substitutions included in each allele are provided at the right of the mutant alleles. $(B)$ Coimmunoprecipitations of signaling proteins with the indicated allele of Fgfr $1^{- \text {Flag3x }}$ in $3 \mathrm{~T} 3$ cells stably expressing the receptor after treatment with $50 \mathrm{ng} /$ $\mathrm{mL}$ FGF1 and $5 \mu \mathrm{g} / \mathrm{mL}$ heparin. Fgfr $1^{- \text {Flag3x }}$ loading was performed on the same membrane as each coimmunoprecipitation. Plc $\gamma$ and CrkL immunoblots were run on the same membrane and therefore have the same Fgfr1 ${ }^{- \text {Flag3x }}$ loading; the Frs2 immunoblot was run on a different membrane. (IP) Immunoprecipitation; (IB) immunoblot. 
plex as previously shown (Mohammadi et al. 1991; Larsson et al. 1999; Dhalluin et al. 2000; Ong et al. 2000; Reilly et al. 2000).

\section{Fgfr1 contributes to primitive endoderm formation}

Fgfr1-related phenotypes are subject to variation depending on the genetic background (Hoch and Soriano 2006; Calvert et al. 2011). To minimize phenotypic variability, we analyzed mouse mutants on 129S4 coisogenic or congenic genetic backgrounds. Previous studies on mixed genetic backgrounds have implicated Fgfrl in epiblast proliferation and mesoderm formation in the post-implantation and gastrulation stages of mouse development (Deng et al. 1994; Yamaguchi et al. 1994; Ciruna et al. 1997; Ciruna and Rossant 2001). On the 129S4 genetic background, however, Fgfr1 $1^{-/-}$mutants die earlier than previously reported (Deng et al. 1994; Yamaguchi et al. 1994; Hoch and Soriano 2006) and fail to be recovered at Mendelian ratios as early as embryonic day 6.5 (E6.5) (Fig. 2A).

Although Fgfr1 is known to function in the post-implantation epiblast (Deng et al. 1994; Yamaguchi et al. 1994; Ciruna and Rossant 2001), Fgfr1 transcripts are detectable in both the epiblast and the primitive endo-
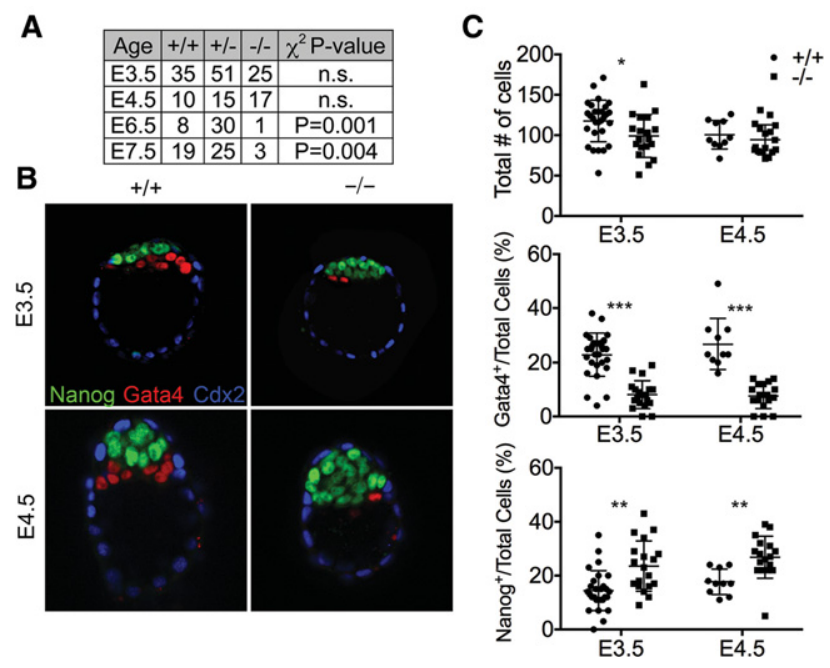

Figure 2. Fgfrl contributes to primitive endoderm formation. (A) Inheritance frequencies of the indicated genotypes at E3.5E7.5, demonstrating that $\mathrm{FgfrI}^{-/-}$mutants fail to be recovered at Mendelian ratios by E6.5. Embryonic fragments recovered at E6.5 and E7.5 had no defined axis or structure (not shown). $\chi^{2}$ test $P$-values were used to evaluate whether inheritance frequencies differ from the predicted Mendelian genotypic ratio of 1:2:1. (n.s.) Not significant. (B) Embryos stained for Gata4, Nanog, and Cdx2 demonstrate that $\mathrm{Fgfr}^{-/-}$mutants form fewer primitive endoderm $\left(\mathrm{Gata}^{+}\right)$and more epiblast $\left(\mathrm{Nanog}^{+}\right)$cells in cultured E3.5 blastocysts and uncultured E4.5 embryos. (C) Quantification representing the total number of cells per embryo and the percentages of primitive endoderm or epiblast lineages; data are presented for individual embryos as well as mean \pm standard deviation. $\left(^{*}\right) P<0.05 ;\left(^{* *}\right) P<0.005 ;\left(^{* * *}\right) P<0.0005, P$-values represent unpaired, two-tailed $t$-test. derm of E3.5 blastocysts (Ohnishi et al. 2013). E3.5 embryos were recovered and cultured for $48 \mathrm{~h}$, and the trophectoderm, epiblast, and primitive endoderm lineages were analyzed. Immunostaining indicated that $\mathrm{Fgfr}^{-/-}$ blastocysts contained significantly fewer Gata4 $4^{+}$primitive endoderm cells and more $\mathrm{Nanog}^{+}$epiblast cells (Fig. 2B,C). This was also observed in uncultured E4.5 embryos, indicating that Fgfr1 regulates primitive endoderm and epiblast lineage restriction in vivo. Fgfrl was previously not known to contribute to primitive endoderm formation; however, similar defects have been observed in other Fgf signaling pathway components (Feldman et al. 1995; Arman et al. 1998; Goldin and Papaioannou 2003; Chazaud et al. 2006; Yamanaka et al. 2010; Kang et al. 2013). Primitive endoderm and epiblast cells are generated from a common inner cell mass precursor. Fgf signaling promotes the primitive endoderm cell fate, and therefore decreases in Fgf signaling generate an inner cell mass composed of fewer primitive endoderm cells and more epiblast cells (Nichols et al. 2009; Yamanaka et al. 2010; Kang et al. 2013). Cultured E3.5 Fgfr1 ${ }^{-/-}$blastocysts also contained fewer cells than controls; however, the numbers of cells per embryo were comparable between $\mathrm{Fgfr}^{-1-}$ mutants and controls in vivo by E4.5 (Fig. 2B,C). Analysis of E5.5 decidua by sectioning and histological analysis revealed the presence of retarded embryos, which could not be unambiguously identified as $\mathrm{Fg} f \mathrm{H}^{-/-}$mutants.

\section{Fgfr1 signaling through CrkL, Plcy, and Grb14 is dispensable for embryonic development}

Previous studies have implicated CrkL as an adaptor protein mediating Fgfr1 and Fgfr2 signaling in multiple neural crest cell (NCC) derivatives (Moon et al. 2006). To test the functional requirements for Fgfr 1-CrkL signaling in vivo, we generated mice harboring a Y463F mutation (Fgfr $1^{C}$ allele) previously shown to disrupt Fgfr1-Crk complex formation (Fig. 1B; Larsson et al. 1999). Fgfr $1^{C / C}$ mutants were viable and fertile and showed growth rates comparable with those of controls (Fig. 3A,B). No skeletal abnormalities were observed in $F g f r 1^{\mathrm{C} / C}$ mutants at birth (data not shown). Using a phenotyping strategy previously used to evaluate viable mouse mutants (Schmahl et al. 2007), complete blood count and serum chemistries were comparable in control and $F g f r 1^{C / C}$ mutants (Supplemental Table 1). Collectively, these data suggest that Fgfr1-CrkL signaling is dispensable for embryonic development and adult physiology.

We next investigated the consequences of disrupting all known Fgfr1 signaling functions except for the Fgfr1Frs2 interaction. To test the functional requirements for the Fgfr1-CrkL, Fgfr1-Plcy, and Fgfr1-Grb14 pathways in vivo, we generated mice harboring Y463F, Y766F, and Y776F mutations (Fgfr1 ${ }^{C P G}$ allele) previously shown to disrupt these protein complexes (Fig. 1B; Mohammadi et al. 1991; Larsson et al. 1999; Reilly et al. 2000). Fgfr ${ }^{C P G / C P G}$ mutants were viable and fertile and showed growth rates comparable with those of controls (Fig. 3A,B). A modest subset of Fgfr $1^{C P G / C P G}$ mutants $(n=2 / 15)$ exhibited defects of the most posterior thoracic vertebrae, 


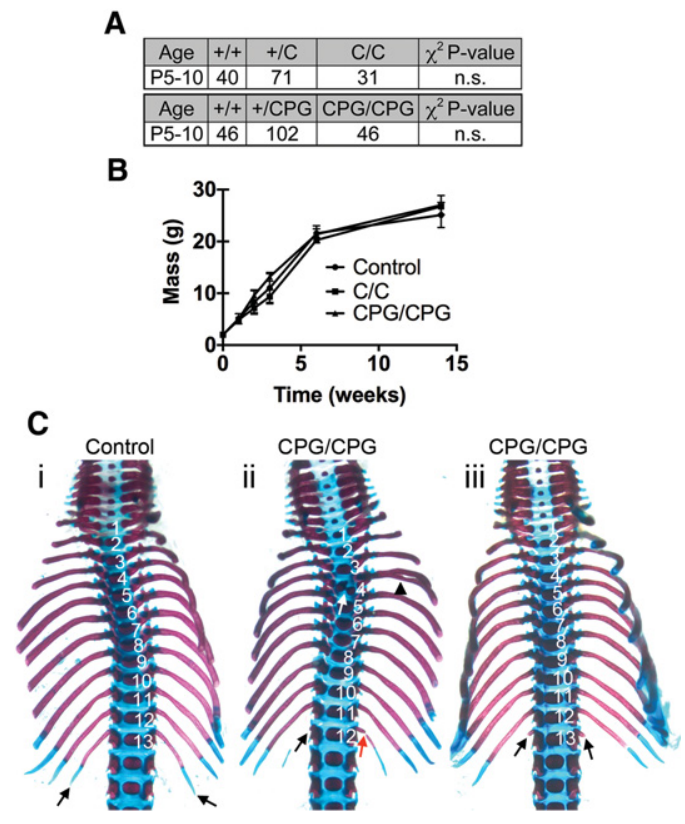

Figure 3. Fgfrl signaling through CrkL, Plc $\gamma$, and Grb14 is not required for embryonic development. $(A)$ Inheritance frequency of the indicated genotypes at postnatal days 5-10 (P5-P10); Fgfr $1^{C / C}$ and Fgfr $1^{\mathrm{CPG} / C P G}$ mutants are inherited at Mendelian ratios. $\chi^{2}$ test $P$-values were used to evaluate whether inheritance frequencies differ from the predicted Mendelian genotypic ratio of $1: 2: 1$. (n.s.) Not significant. (B) Growth curves indicating that postnatal growth is normal in $F g f r 1^{C / C}$ and $F g f r 1^{C P G / C P G}$ mutants. Data are indicated as mean \pm standard deviation. $n=5 .(C)$ Ventral view of P0 skeletal preparations demonstrating defects of the most posterior thoracic vertebrae and ribs found at a low penetrance in Fgfr $1^{C P G / C P G}$ mutants $\left(F g f r 1^{C P G / C P G}, n=2 / 15\right.$; control, $n=15)$. (Panels ii,iii) Both affected Fgfr ${ }^{C P G / C P G}$ mutants are shown. (Panel i) Note that 13 thoracic vertebrae (numbered) are present and the size of the 13th rib (black arrows) in control embryos. (Panel ii) Thoracic vertebrae are numbered to illustrate that one thoracic vertebra is missing in this Fgfr1 ${ }^{C P G / C P G}$ mutant. The ossification center of the fourth thoracic vertebra is duplicated (white arrow), and the attached rib is bifurcated (black arrowhead). Also note the rib rudiment present on one side of the 12th thoracic vertebrae (black arrow) and the separated distal element of the rib (red arrow). (Panel iii) Thoracic vertebrae are numbered; note the small rib rudiments present on the 13th thoracic vertebra (black arrows) in the Fgfr $1^{C P G / C P G}$ mutant.

indicating that Fgfrl signaling through one or more of these pathways functions in patterning the anterior-posterior axis during development (Fig. 3C). The number of lumbar vertebrae varied between five (wild type, $n=11$ / 15; Fgfr $1^{C P G / C P G}, n=9 / 15$ ) and six (wild type, $n=4 / 15$; Fgfr1 $\left.{ }^{C P G / C P G}, n=6 / 15\right)$ at similar frequencies in both wild type and Fgfr1 $1^{C P G / C P G}$ mutants. Both Fgfr1 ${ }^{C P G / C P G}$ mutants with axial skeleton defects had five lumbar vertebrae. Interestingly, similar defects were observed at higher penetrance and expressivity in Fgfrl-Plc $\gamma$-deficient

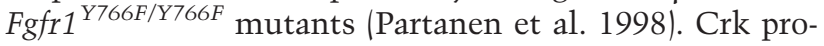
teins are positive effectors of Fgfr1 signaling (Larsson et al. 1999; Moon et al. 2006), while Plc $\gamma$ is a negative regulator (Sorokin et al. 1994; Partanen et al. 1998). It is there- fore possible that loss of Fgfrl signaling through Crk proteins attenuates the mild gain-of-function allele conferred by loss of Plc $\gamma$ signaling. Alternatively, the differences in phenotypic severity between Fgfr1 ${ }^{\text {Y766F/Y766F }}$ and Fgfr1 ${ }^{C P G / C P G}$ mutants could be due to genetic background. The fourth rib was bifurcated in one Fgfr1 ${ }^{C P G / C P G}$ mutant, and the ossification center of this vertebra was duplicated, although this was not observed in other Fgfr1 ${ }^{C P G / C P G}$ mutants (Fig. 3C). Complete blood count and serum chemistries were comparable in control and Fgfr1 $1^{C P G / C P G}$ mutants (Supplemental Table 2). Collectively, these data suggest that, although Fgfrl signaling through one or more of these pathways is important for anterior-posterior patterning, these pathways are largely dispensable for embryonic development and adult physiology.

\section{Frs2 regulates a subset of Fgfr1 signaling in vivo}

To test the functional requirements for Fgfr1-Frs2 signaling in vivo, we generated mice harboring L423A and V429A mutations (Fgfr $1^{F}$ allele) previously shown to disrupt Fgfr1-Frs2 binding (Fig. 1B; Dhalluin et al. 2000; Ong et al. 2000). Fgfr $1^{F / F}$ mutants were recovered at Mendelian ratios at birth but died shortly thereafter (Fig. 4A). Examination of postnatal day 0 (P0) skeletons indicated that Fgfr1-Frs2 signaling is essential in numerous developmental contexts. Fgfr $1^{F / F}$ mutants exhibited cleft palate, hypoplasia of multiple middle ear bones, postaxial polydactyly, and an additional thoracic vertebra (Fig. 4C-J). The middle ear defects and postaxial polydactyly observed in Fgfr1 $1^{F / F}$ mutants varied in expressivity (Supplemental Fig. S2). Fgfr1 $1^{F / F}$ phenotypes also varied in penetrance (Fig. 4B), suggesting that additional signaling pathways are at least partially capable of compensating for loss of Fgfr1-Frs2 signaling in vivo. These data indicate that Fgfr1-Frs2 signaling regulates only a subset of Fgfr1 functions in vivo, since the $F g f r 1^{F / F}$ mutants fail to recapitulate the $\mathrm{Fgfr}^{-/-}$phenotype.

\section{Fgfr1 uses multiple proteins additively in vivo}

We next examined the consequences of disrupting all established signaling functions of Fgfrl by disrupting Fgfr1-Frs2, Fgfr1-CrkL, Fgfr1-Plc $\gamma$, and Fgfr1-Grb14 signaling in vivo. To achieve this, we generated mice harboring L423A, V429A, Y463F, Y766F, and Y776F mutations (Fgfr1 $1^{F C P G}$ allele). Fgfr $1^{\text {FCPG/FCPG }}$ mutants were recovered at Mendelian ratios up to E10.5 but failed to develop past E9.5 (Fig. 5). Fgfr $1^{\text {FCPG/FCPG }}$ mutants had severe posterior truncations and subepidermal blebs and appeared developmentally retarded compared with control littermates (Fig. 5A). Although defects associated with yolk sac vasculature and chorioallantoic fusion commonly cause lethality at E9.5, these processes appeared normal in Fgfr $1^{\text {FCPG/FCPG }}$ mutants (data not shown). In situ expression of $F g f 3$ and Meox1 indicated that Fgfr1 $1^{F C P G / F C P G}$ mutants form mesoderm and somites at the E7.5 and E9.5 stages, respectively (Supplemental Fig. S3), although somites were small and irregular. The Fgfr1 $1^{F C P G / F C P G}$ mutants therefore also exhibit less severe phenotypes than previously published 


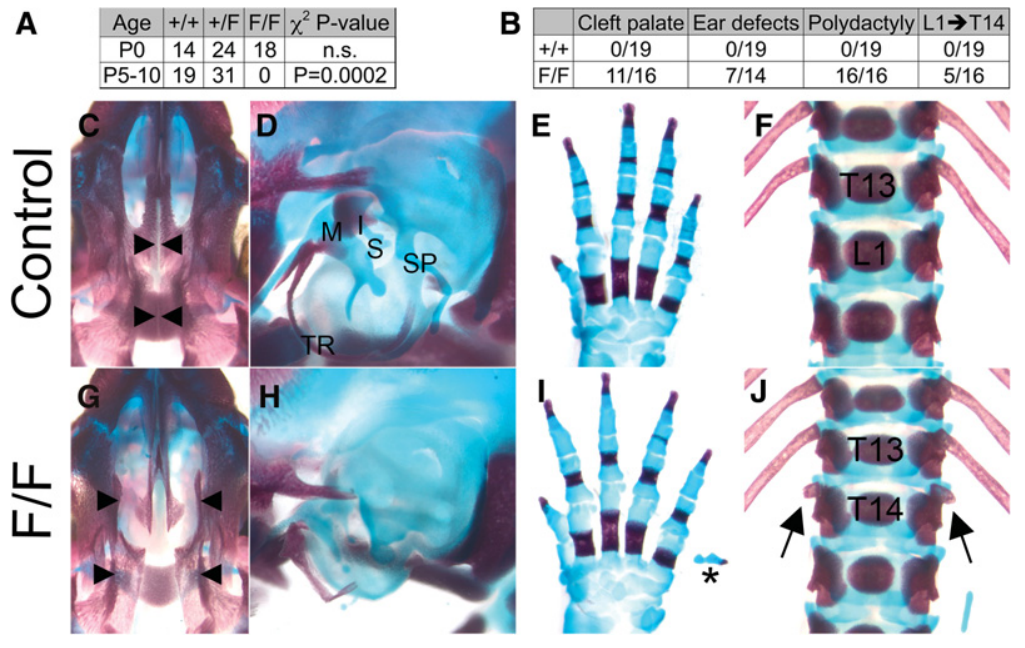

Figure 4. Fgfr1-Frs2 signaling is essential for embryonic development. (A) Inheritance frequencies of genotypes at postnatal days indicates that $F g f r 1^{F / F}$ mutants die perinatally. $\chi^{2}$ test $P$-values were used to evaluate whether inheritance frequencies differ from the predicted Mendelian genotypic ratio of 1:2:1. (n.s.) Not significant. (B) Penetrance of the skeletal defects shown in $C-J$. $(C-J)$ Skeletal preparations of neonatal controls $(C-F)$ and $F g f r 1^{F / F}$ mutants $(G-J)$. Fgfr1 ${ }^{F / F}$ mutants exhibit multiple skeletal defects, including cleft palate $(G)$, hypoplastic middle ear bones $(H)$, postaxial polydactyly $(I)$, and one additional thoracic vertebra $(J) .(C, G)$ Ventral view of the skull; arrowheads indicate the most medial aspect of the palate in control $(C)$ and $F g f r 1^{F / F}$ mutants $(G) .(D, H)$ Side view of middle ears $(D)$ shows that the tympanic ring (TR), malleus $(M)$, incus (I), stapes (S), and styloid process (SP) are hypoplastic in $F g f r 1^{F / F}(H)$ mutants. $(E, I)$ Dorsal view of the forelimb of control $(E)$ and Fgfr $1^{F / F}$ mutants $(I)$. The asterisk indicates postaxial polydactyly. $(F, J)$ Ventral view of thoracic $(\mathrm{T})$ and lumbar $(\mathrm{L})$ vertebrae of control $(F)$ and $F g f r 1^{F / F}(J)$ mutants. (J) Arrows indicate small ribs growing from the 14th thoracic vertebra (T14) in Fgfr $1^{F / F}$ mutants.
Fgfr1-null alleles on mixed genetic backgrounds (Deng et al. 1994; Yamaguchi et al. 1994).

Frs3 may be capable of binding the Fgfr $1^{F C P G}$ allele and therefore may contribute to mesoderm formation; however, Frs3 transcripts were detectable only at very low levels in both wild-type and $F g f r 1^{F C P G / F C P G}$ mutant embryos at E7.5 and E8.5 (2\% of $\beta_{2}$ microglobulin) (Supplemental Fig. S4). This is consistent with previous studies demonstrating that Frs3 expression is not detectable by in situ hybridization at E7.5 or E8.5 (McDougall et al. 2001; Gotoh et al. 2004a) and suggests that Frs3 does not contribute to early developmental functions of Fgfr1.

The relative severity of the $F g f r 1^{F C P G / F C P G}$ phenotypes compared with Fgfr $1^{C P G / C P G}$ and $F g f r 1^{F / F}$ mutants indicates that Fgfrl uses multiple signaling proteins additively in vivo. However, the failure of $F g f r 1^{F C P G / F C P G}$ mutants to recapitulate the $\mathrm{Fgfr}_{\mathrm{r}} \mathrm{I}^{-/}$phenotype also suggests that some functions of Fgfrl remain intact in Fgfr $1^{F C P G / F C P G}$ mutants.

\section{Fgfr1 signaling requirements are context-specific}

The relative severities of the $F g f r 1^{C P G / C P G}, F g f r 1^{F / F}$, and Fgfr $1^{F C P G / F C P G}$ phenotypes indicate that Fgfrl uses multiple proteins additively in vivo and that together these pathways account for a subset of Fgfrl functions. To test the model that Fgfrl signals additively through multiple proteins, we used the second PA (2nd PA) as a readout of Fgfrl function in the $F g f r 1^{F / F}$ and $F g f r 1^{F C P G / F C P G}$ mutants. Fgfr1 is required in the 2nd PA ectoderm as a permissive factor that allows NCCs to populate the 2nd PA (Trokovic et al. 2003, 2005; Hoch and Soriano 2006). Decreased Fgfr1 function results in failure of NCCs to enter the 2nd PA and hypoplasia of this tissue (Trokovic et al. 2003, 2005; Hoch and Soriano 2006). The 2nd PAs of Fgfr $1^{F C P G / F C P G}$ mutants were completely absent (Fig. 6A), and wholemount in situ hybridization of NCC marker Crabp1 confirmed that NCCs failed to enter the 2nd PA (data not shown), whereas the 2nd PAs of $F g f r 1^{F / F}$ mutants were hypoplastic (Fig. 6A). The intermediate phenotype of the Fgfr $1^{F / F}$ mutants relative to controls and Fgfr $1^{F C P G / F C P G}$ mutants further supports the model that Fgfr1 signals additively through multiple proteins.

To re-examine these alleles in NCCs and craniofacial development, the $F g f r 1^{F}$ and $F g f r 1^{F C P G}$ alleles were combined with a conditional null Fgfr1 allele (Hoch and Soriano 2006) and the Wnt1-Cre driver, which is expressed in the dorsal neural tube and labels NCCs as they delaminate (Danielian et al. 1998). Both $F g f r 1^{F / c K O}$ and Fgfr $1^{F C P G / C K O}$ mutants exhibited cleft palate at low penetrance $\left(F g f r 1^{F / c K O}, n=1 / 7 ; F g f r 1^{F C P G / c K O}, n=2 / 13\right)$, while Fofr $1^{\text {cKO/CKO }}$ mutants exhibited a fully penetrant midline facial cleft (Fig. 6B). In contrast to the germline mutations, Fgfr $1^{F / C K O}$ and $F g f r 1^{F C P G / C K O}$ conditional mutants phenocopy each other in craniofacial development, suggesting that Fgfrl signaling requirements are context-specific. This context specificity could reflect a threshold requirement for Fgf signaling in palate development. Alternatively, it is possible that Crk proteins, Plc $\gamma$, and Grb14 do not contribute for Fgfrl signaling in the palate. Consistent with analysis of the germline mutations, conditional Fgfr $1^{F C P G / c K O}$ mutants failed to recapitulate $F g f r 1^{c K O / c K O}$ mutants, suggesting that some unknown functions of Fgfrl remain intact in the $F g f r 1^{F C P G}$ allele.

\section{Loss of Stat3 fails to enhance Fgfr ${ }^{\mathrm{FCPG} / \mathrm{cKO}}$ phenotypes}

Previous reports have demonstrated that Stat 3 is activated by Fgfrl in cancer cell lines (Dudka et al. 2010). To investigate whether Fgfrl-Stat3 signaling is important during development, primary cells were derived from E11.5 maxillary and nasal prominences (hereafter referred to as facial prominence cells [FPCs]) (Vasudevan and Soriano 2014). These cells provide an in vitro model to study the biochemical properties of Fgf signaling in Fgfr1 or Stat3 wild-type and mutant conditions. We observed Stat3 


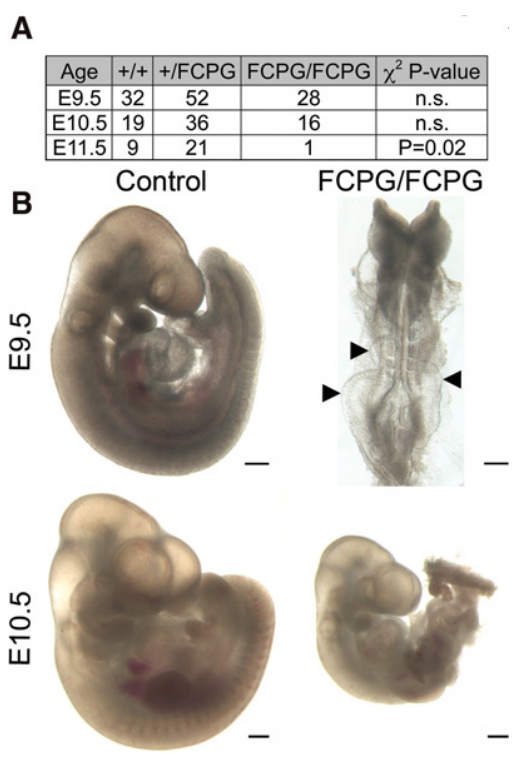

Figure 5. Fgfrl signals additively using multiple pathways in vivo. (A) Inheritance frequencies of the indicated genotypes and embryonic days, suggesting that $F g f r 1^{F C P G / F C P G}$ mutants die between E10.5 and E11.5. $\chi^{2}$ test $P$-values were used to evaluate whether inheritance frequencies differ from the predicted Mendelian genotypic ratio of $1: 2: 1$. (n.s.) Not significant. $(B)$ Fgfr $1^{F C P G / F C P G}$ embryos exhibit multiple defects in embryonic development, including highly penetrant developmental retardation, posterior truncations, and epidermal blebbing (arrowheads). Bars, $250 \mu \mathrm{m}$.

nuclear translocation in FPCs stimulated with FGF1, indicating that Stat 3 is activated by Fgf signaling (Supplemental Fig. S5A). Stat3 and Fgfr1 also coimmunoprecipitated in $3 \mathrm{~T} 3$ cells that stably expressed either Fgfr ${ }^{\text {WT-Flag3x }}$ or Fgfr $1^{\text {FCPG-Flag3x }}$ (Supplemental Fig. S5B), suggesting that Fgfr1 and Stat 3 are capable of forming a protein complex that is not disrupted by the Fgfr1 ${ }^{F C P G}$ allele. To test whether Stat 3 is functionally required downstream from Fgfr1, we conditionally knocked out Stat3 in NCCs of Fgfr $1^{\text {FCPG/CKO }}$ mutants using the Wnt1-Cre driver and a floxed Stat3 allele (Takeda et al. 1998). Conditional ablation of Stat3 alone in NCCs failed to produce any obvious developmental defects, as these mice were viable with normal craniofacial skeletons (data not shown). Similarly, loss of Stat 3 combined with the Fgfr $1^{\text {FCPG/CKO }}$ mutant did not enhance the lowly penetrant cleft palate seen in Fgfr $1^{F C P G / C K O}$ mutants (Supplemental Fig. S5C). Cleft palate was not observed in any Stat3 $3^{c K O / c K O}$, Fgfr $1^{F C P G / c K O}$ double mutants $(n=4)$, likely due to the low penetrance of cleft palate found in Fgfr1 $1^{F C P G / c K O}(n=2 / 13)$. These data suggest that Stat3 either is not functional or is redundant downstream from Fgfrl in NCCs and craniofacial development.

Fgfr1 uses multiple proteins to activate Erk1/2 and Plcy in vitro

To examine which pathways are activated following FGF1 stimulation in primary cells, we performed a time course using mouse embryonic fibroblasts (MEFs) and assayed activation of several pathways known to be regulated by RTKs. Erk1/2, Plc $\gamma$, and Jnk signaling were induced following FGF1 stimulation, while PI3K/Akt, Src family kinases (Sfk), Stat5, and p38 were not activated by FGF1 treatment (Supplemental Fig. S6A). We therefore focused on pathways activated by FGF1 stimulation in subsequent analysis but also included PI3K/Akt because of its common association with Fgfr signaling.

We next generated FPCs to evaluate intracellular pathway activation in each of the mutants. Erk $1 / 2$ activation was not altered in $F g f r 1^{C / C}$ or Fgfr $1^{C P G / C P G}$ mutants (Supplemental Fig. S6B) but was lower in $F g f r 1^{F / c K O}$ and was reduced to a greater extent in Fgfr $1^{\text {FCPG/CKO }}$ mutants relative to controls (Fig. 7). The decreased Erk $1 / 2$ activation in Fgfr $1^{F C P G / c K O}$ mutants relative to $F g f r 1^{F / c K O}$ mutants demonstrates a functional role for CrkL, Plc $\gamma$, and/or Grb14 in Erk1/2 activation and further supports the model that Fgfr1 uses multiple signaling proteins additively. Interestingly, Erk $1 / 2$ activation was comparable in Fgfr $1^{F C P G / C K O}$ and Fgfr $1^{c K O / c K O}$ FPCs at $10 \mathrm{~min}$. At 5 min, however, Fgfr $1^{F C P G / c K O}$ mutants retained some Erk1/2 activity relative to $F g f r 1^{c K O / c K O}$ mutant FPCs. Erk1/2 activity was therefore diminished but not completely eliminated by the Fgfr $1^{F C P G}$ allele. The residual Erk1/2 activation observed in Fgfr $1^{\mathrm{cKO} / \mathrm{cKO}}$ FPCs is likely due to signaling through another Fgfr, as FGF1 is capable of activating all Fgfrs.

As expected, Plc $\gamma$ activation was not affected in $F g f r 1^{C / C}$ cells but was decreased in Fgfr $1^{C P G / C P G}$ cells (Supplemental Fig. S6B). Unexpectedly, Plc $\gamma$ activation was lower in Fgfr $1^{\text {F/CKO }}$ mutants (Fig. 7), indicating that a subset of

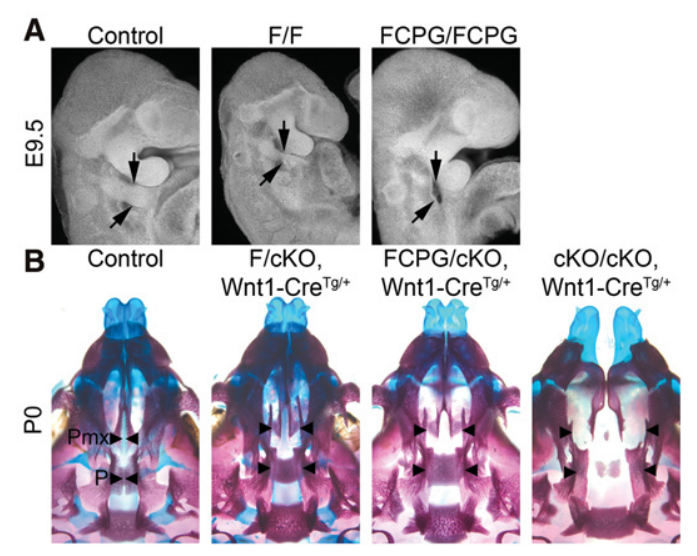

Figure 6. Fgfr1 signaling requirements are context-specific. $(A)$ Lateral view of E9.5 2nd PAs (arrows) imaged using nuclear fluorescence imaging (Sandell et al. 2012). Fgfr1 $1^{F / F}$ mutant 2 nd PAs were hypoplastic $(n=3)$, while Fgfr $1^{\text {FCPG/FCPG }}$ mutants $(n=5)$ failed to form 2nd PAs. Fgfr1 $1^{F C P G / F C P G}$ embryos were dissected at E10.5 and stage-matched with E9.5 control embryos to account for developmental retardation. (B) Ventral views of P0 skulls demonstrating that the palatine $(\mathrm{P})$ and palatal process of the maxilla $(\mathrm{Pmx})$ are clefted (arrowheads) in both $\operatorname{Fgfr}^{\mathrm{F} / \mathrm{CKO}}(n=1 / 7)$ and Fgfr1 $1^{F C P G / c K O}(n=2 / 13)$ mutants, while all Fgfr $1^{\text {cKO/cKO }}$ mutants exhibit facial clefting $(n=16 / 16)$. (cKO) Conditional knockout achieved with the Wnt1-Cre driver; (Tg) transgene. 


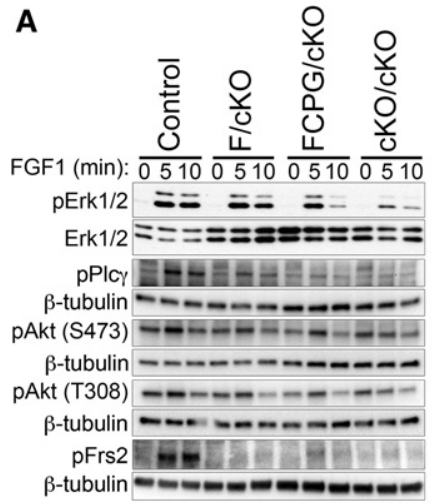

B

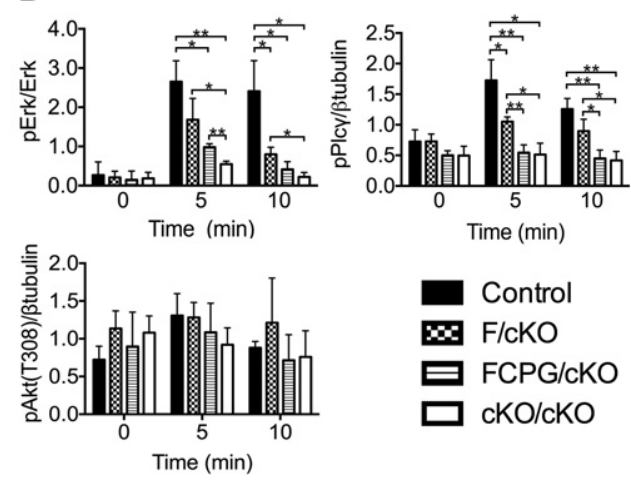

Figure 7. Fgfr1 uses multiple proteins to activate $\operatorname{Erk} 1 / 2$ and PLC $\gamma$ in vitro. $(A)$ FPCs derived from the indicated genotypes were serumstarved overnight and stimulated with $50 \mathrm{ng} /$ mL FGF1 and $5 \mu \mathrm{g} / \mathrm{mL}$ heparin for the indicated times. Phospho-blots were stripped and reblotted with total protein or $\beta$-tubulin for loading controls. (B) Quantification of pathway activation normalized to the loading control, reported as mean \pm standard deviation with a minimum of three independent biological replicates. (*) $P \leq 0.05$; (**) $P \leq 0.005$, unpaired, two-tailed $t$-test.
Plc $\gamma$ activation is Frs2-dependent. Residual Plc $\gamma$ activation observed in the Fgfr1 $1^{C P G / C P G}$ mutants may be due to Fgfr1-Frs2 signaling. These data therefore suggest that $\mathrm{Plc} \gamma$ is activated directly by Fgfr1 in a Tyr766-dependent manner and indirectly downstream from Fgfr1-Frs2 signaling. Plc $\gamma$ activation was disrupted to a similar extent in Fgfr $1^{F C P G / c K O}$ and Fgfr $1^{c K O / c K O}$ mutants (Fig. 7).

A comparison of Jnk activation between each signaling mutant produced highly variable results that may be consistent with FGF1-mediated Jnk activation being dependent on another Fgfr (Supplemental Fig. S6C). Notably, Jnk activation was often increased in mutant cells without FGF1 treatment.

PI3K/Akt signaling was monitored using pS473- and pT308-specific antibodies with similar results (Fig. 7). Akt phosphorylation increased following 5 min of FGF1 treatment in control but not Fgfr $1^{c K O / c K O}$ cells. FGF1-dependent phosphorylation of Akt was consistently observed in Fgfr $1^{F / c K O}$ and Fgfr $1^{F C P G / c K O}$ cells (Fig. 7A), but the amplitude of this change did not allow statistical validation (Fig. 7B). Previous studies have demonstrated that PI3K/Akt activation by Fgfr1 depends on Fgfr1-Frs2 binding and formation of a Fgfr1-Frs2-Grb2-Gab1 protein complex (Ong et al. 2001). Frs2 phosphorylation was also monitored to ensure that the $F g f r 1^{F}$ mutations eliminated Fgfr1-mediated Frs2 activation. Frs2 was phosphorylated following FGF1 treatment in control FPCs, but no phosphorylation was observed in $F g f r 1^{F / c K O}, F g f r 1^{F C P G / c K O}$, or Fgfr $1^{c K O / c K O}$ FPCs (Fig. 7A). This indicates that Fgfr1 is capable of activating PI3K/Akt in part through an unknown Frs2-independent mechanism. Fgfr1 ${ }^{\text {FCPG/CKO }}$ mutants therefore seem to maintain an ability to activate PI3K/Akt but show a strongly diminished ability to activate Erk1/2 and Plc $\gamma$, raising the possibility that PI3K/ Akt signaling contributes to the phenotypic differences between Fgfr $1^{F C P G}$ and Fgfr1-null alleles.

\section{Discussion}

Using genetic and biochemical approaches, we interrogated the functional relevance of many signaling proteins engaged following Fgfr1 activation. Frs 2 and Erk1/2 are widely considered the primary signaling proteins used by Fgfrs (Eswarakumar et al. 2005). Our data support the idea that Frs 2 and Erk1/2 are important signaling proteins used by Fgfrs, but we also propose that multiple signaling proteins mediate the cumulative activities of Fgfrs.

Loss of Frs2 binding to Fgfr1 caused perinatal lethality and affected multiple contexts, suggesting that Fgfr1Frs2 signaling functions pleiotropically in development. Despite the obvious importance of Frs2 in Fgfr1 signaling, all Fgfr1 signaling functions cannot be attributed to Frs2, since Fgfr1 $1^{F / F}$ mutants showed a dramatically less severe phenotype than Fgfr1 $1^{-/-}$mutants. Similarly, Fgfr1 ${ }^{F / c K O}$ signaling mutants showed only modest decreases in Erk1/2 activation, suggesting that other pathways are also important for activating the Erk $1 / 2$ signaling cascade. Unexpectedly, Frs2 was also required for maximal activation of Plc $\gamma$. The phenotype that we observed for $F g f r 1^{F / F}$ mutants was less severe than that observed previously for Fgfr $1^{\triangle F R S / \triangle F R S}$ embryos harboring a deletion of the juxtamembrane region required for Frs2 and Frs3 binding (Hoch and Soriano 2006). Fgfr1 $1^{F / F}$ and Fgfr $1^{\triangle F R S / \triangle F R S}$ mutants had similar defects in the 2nd PA and middle ear, but the midgestation lethality of the Fgfr1 ${ }^{\triangle F R S / \triangle F R S}$ mutants prohibited direct comparisons. Fgfr1 $1^{\triangle F R S / \triangle F R S} \mathrm{mu}$ tants also had a number of phenotypes not found in Fgfr $1^{F / F}$ mutants, such as posterior truncations and neural tube defects. These phenotypic differences are unlikely to all be due to Fgfr1 signaling through Frs3, since Frs3 is not expressed broadly but is instead restricted to specific tissues later in development (McDougall et al. 2001; Gotoh et al. 2004a). Instead, the disparity between phenotypes could reflect differences in the allele design. The Fgfr $1^{\triangle F R S / \triangle F R S}$ allele was indeed generated using a partial cDNA approach that led to neonatal lethality in a control experiment with a wild-type cDNA, suggesting that this approach does not faithfully recapitulate the expression of Fgfrl. It is also possible that the deletion of amino acids 407-433 in Fgfr $1^{\triangle F R S / \triangle F R S}$ mutants prevents the binding of additional yet unidentified signaling molecules that participate in Fgfr1 functions.

Other individual signaling pathway mutants interrogating Crk proteins or Plc $\gamma$ signaling requirements individually were viable and fertile. We observed that Fgfrl signaling through Crk proteins is dispensable for 
embryonic development and adult homeostasis. Additionally, Fgfr $1^{C / C}$ mutants had normal activation of all assayed pathways. Disruption of Plc $\gamma$ signaling led to modest patterning defects of the vertebrae (Partanen et al. 1998). Surprisingly, Fgfr $1^{C P G / C P G}$ mutants disrupted all known signaling functions except for Frs2, but these mice were viable and fertile with only modest defects, reminiscent of loss of Fgfrl-Plc $\gamma$ signaling (Partanen et al. 1998).

The less severe nature of $F g f r 1^{F / F}$ and $F g f r 1^{C P G / C P G}$ phenotypes relative to $F g f r 1^{F C P G / F C P G}$ indicates that Fgfr1 uses multiple proteins additively in vivo. This model was supported biochemically, since Erk1/2 and Plc $\gamma$ activation was lower in Fgfr1 $1^{F C P G / C K O}$ than Fgfr1 $1^{F / c K O}$ mutants. Since Plc $\gamma$ and Grb14 function as negative regulators of Fgfr1 (Sorokin et al. 1994; Partanen et al. 1998), it is possible that the increased severity associated with the Fofr $1^{F C P G}$ allele is attributable to loss of signaling through Frs 2 and Crk proteins. Alternatively, Plc $\gamma$ has been shown to activate Erk1/2 at the level of Raf (Huang et al. 1995), suggesting that Plc $\gamma$ may function as both a positive effector and a negative regulator of Fgfrl signaling. Additional experiments are necessary to identify whether loss of CrkL, Plc $\gamma$, and Grb14 signaling is necessary for the Fgfr $1^{\text {FCPG/FCPG }}$ phenotype or whether only a subset of these mutations contributes to the phenotype.

The model that Fgfrs use multiple proteins additively is in contrast to an alternative mechanism proposed in Xenopus, where Fgf signaling uses Erk $1 / 2$ and Plc $\gamma$ modularly (Nutt et al. 2001; Sivak et al. 2005). Here, Erk1/2 specifies mesoderm, and $\mathrm{Plc} \gamma$ later regulates convergent extension. The differences between these models could represent divergent signaling mechanisms across species or differences in experimental paradigms. Our study interrogated signaling events proximal to the receptor and therefore only affected Fgfrl-dependent signaling. This strategy, however, cannot be used to directly interrogate the requirement of Erk1/2 or PI3K/Akt because these pathways are activated indirectly through multiple adaptors. Other studies modulated Xtspred and Xtsprouty proteins, which are thought to negatively regulate Erk $1 / 2$ and $\mathrm{Plc} \gamma$, respectively, and are therefore more able to assay the requirements of specific pathways; however, this approach also has caveats. Xtspred and Xtsprouty could have Erk1/2and $\mathrm{Plc} \gamma$-independent functions, which complicates analysis. Additionally, this approach modulates each pathway irrespective of the source of Erk1/2 and Plc $\gamma$ activation, and therefore conclusions cannot be attributable to an individual Fgfr or even RTK.

The Fgfr $1^{\text {FCPG }}$ mutation failed to recapitulate Fgfr1-null phenotypes in preimplantation and craniofacial development, indicating that Fgfrl possesses additional functions not disrupted in the Fgfr $1^{F C P G}$ allele. The preimplantation requirement for Fgfrl in primitive endoderm formation is unexpected, since multiple null alleles of Fgfr1 have been shown to die later during gastrulation (Deng et al. 1994; Yamaguchi et al. 1994), including the same Fgfr1-null allele as used in this study on a mostly C57BL/6J background (Hoch and Soriano 2006). This developmental requirement was most likely not observed in previous
Fgfr1 ${ }^{-/-}$studies due to differences in genetic backgrounds, which have been shown to influence Fgfr1-associated phenotypes (Calvert et al. 2011).

Interestingly, phosphorylation of Akt was still observed in Fgfr $1^{F C P G / C K O}$ primary cells. The PI3K/Akt pathway could therefore contribute to residual function of the Fgfr $1^{F C P G}$ allele. Previous studies demonstrated that PI3K/Akt is activated downstream from Fgfr1 in a Frs2-dependent pathway (Ong et al. 2001). Since Frs 2 cannot bind the Fgfr $1^{F C P G}$ allele, this suggests that Fgfrl is also capable of activating PI3K/Akt in a Frs2-independent pathway. Interestingly, recent studies demonstrated that PI3K is capable of binding Y730 of Fgfr1 during prolonged receptor activation (Francavilla et al. 2013) to regulate Akt-independent receptor recycling. Whether this Fgfr1-PI3K complex is responsible for the residual function of the Fgfr $1^{F C P G}$ allele will require further investigation.

Although Erk1/2 and Plc $\gamma$ were decreased, it still remains possible that residual signaling through these pathways is responsible for the phenotypic differences between Fgfr $1^{F C P G}$ and Fgfr1-null alleles. Additionally, proteomic studies have identified signaling proteins with novel FGF-induced tyrosine phosphorylation (Hinsby et al. 2003; Francavilla et al. 2013), providing other candidates for investigation. Analysis of Erk1/2, Plc $\gamma$, and PI3K/ Akt activity in vivo rather than in vitro may help identify which pathways are responsible for the phenotypic differences between Fgfr1 ${ }^{F C P G}$ and Fgfr1-null alleles. A limitation to the in vitro system used to assay pathway activity is the inability to recapitulate the complexities of ligand-receptor association. Many of the developmental contexts that we examined express multiple FGF ligands known to induce different cellular processes by modulating receptor phosphorylation and signaling kinetics (Francavilla et al. 2013).

Our results support a prominent role for Frs 2 and Erk1/2 downstream from Fgfr1; however, Crk proteins, Plc $\gamma$, and Grb14 were also functionally required during embryonic development and contributed to Erk1/2 activation in vitro. These results indicate that Fgfr1 uses multiple signaling proteins additively rather than relying on individual proteins to mediate developmental functions. This mode of regulation likely contributes to the robustness of FGF responses in various developmental and physiological settings.

\section{Materials and methods}

\section{Generation of knock-in mice}

Three distinct targeting vectors carrying the $F g f r 1^{C P G}, F g f r 1^{F}$, and Fgfr $1^{F C P G}$ mutations were generated by cloning a $5^{\prime}$ homology $\operatorname{arm}\left(1.8 \mathrm{~kb}\right.$, EcoRI to PstI, spanning exon 9) and a $3^{\prime}$ homology arm (8.4 kb, PstI to ClaI, spanning exons 10-18) into PGKneolox2DTA.2 (Addgene, no. 13449) (Hoch and Soriano 2006). Sitedirected mutagenesis was performed using Pfu (Stratagene) or Phusion (New England Biolabs) polymerase and was verified by sequencing. Nucleotide substitutions are presented in Supplemental Figure S1. Targeting vectors were electroporated into 129S4 AK7 ES cells, targeting events were screened by PCR coupled with restriction digests to identify incorporation of 
nucleotide substitutions, and proper targeting was confirmed by Southern blotting using $5^{\prime}$ external, $3^{\prime}$ external, internal, and neo probes. The $F g f r 1^{C}$ allele was generated by homologous recombination events that incorporated the Y463F mutation from the $F g f_{r} 1^{C P G}$ targeting vector without incorporating the $\mathrm{Y} 766 \mathrm{~F}$ or Y776F mutations. ES cell chimeras were bred to Meox2-Cre deleter mice (Tallquist and Soriano 2000) maintained on a 129S4 genetic background to remove the neomycin selection cassette, and the Meox2-Cre allele was subsequently crossed out. Two independent mouse lines were generated from independent ES cell clones for each allele, and phenotypes were confirmed in both lines. $F g f r 1^{C}, F g f r 1^{C P G}, F g f r 1^{F}$, and $F g f r 1^{F C P G}$ alleles were maintained on the 129S4 genetic background and genotyped using the following primers that produce different-sized bands for the wild-type (364 base pairs [bp]) and mutant (550 bp) alleles: FGFR1Forward (5'-ACCAAGCACCTGGCTATGGAA-3') and FGFR1Reverse (5'-ACGCTCTGCCAGAGGTACTGA-3').

\section{Mouse strains}

All animal experimentation was conducted according to protocols approved by the Institutional Animal Care and Use Committee of Icahn School of Medicine at Mount Sinai. Fgfr1 ${ }^{\text {tm5.1Sor }}$ and Fgfr ${ }^{\text {tm5.2Sor }}$ were maintained on a 129S4 coisogenic background and are referred to in the text as $F g f r 1^{c K O}$ and $F g f r 1^{-}$, respectively (Hoch and Soriano 2006). Tg(Wnt1-cre)11Rth and Meox $2^{\operatorname{tm} 1(\text { Cre }) \text { Sor }}$ were maintained on 129S4 congenic and coisogenic backgrounds, respectively, and are referred to in the text as Wnt1-Cre and Meox2-Cre (Danielian et al. 1998; Tallquist and Soriano 2000). Stat $3^{\text {tm } 2 A k i}$ was maintained on a mixed genetic background and is referred to in the text as Stat3 ${ }^{\text {cKO }}$ (Takeda et al. 1998).

\section{Statistical analysis of mutant inheritance frequencies}

The $\chi^{2}$ tests were performed using GraphPad QuickCalcs (http://graphpad.com/quickcalcs/chisquared1.cfm) to determine whether observed inheritance frequencies deviated from the predicted 1:2:1 Mendelian genotypic ratio.

\section{Blastocyst immunostaining}

E3.5 blastocysts were isolated and cultured for $48 \mathrm{~h}$ in DMEM with penicillin and streptomycin. E4.5 embryos were isolated and processed without in vitro culture. Embryos were fixed for $30 \mathrm{~min}$ in $4 \%$ PFA and washed $10 \mathrm{~min}$ in PBS with $0.1 \%$ Tween 20, $10 \mathrm{~min}$ in PBS with $3 \mathrm{mg} / \mathrm{mL} \mathrm{PVP}$, and $20 \mathrm{~min}$ in PBS with $3 \mathrm{mg} / \mathrm{mL} \mathrm{PVP}$ and $0.5 \%$ Triton X-100. Embryos were then blocked in $2 \%$ donkey serum, $0.1 \%$ BSA, and $0.1 \%$ Tween 20 in PBS for $2 \mathrm{~h}$ at room temperature. Primary antibodies were incubated in blocking solution overnight at $4^{\circ} \mathrm{C}$, and embryos were washed in PBS with $0.1 \%$ Tween 20 and incubated with a secondary antibody for $2 \mathrm{~h}$ at room temperature in PBS with $1 \%$ donkey serum and $0.1 \%$ Tween 20 . Blastocysts were then washed in PBS and stained for DAPI.

Blastocysts were imaged on a Zeiss Axio-Observer.Z1 with Apotome and Hamamatsu Orca Flash 4.0LT camera and Zen Pro 2012 software. Cells were counted using Metamorph software, and statistics were analyzed using Prism 6.0 software (GraphPad, Inc.).

\section{Generation of Fgfr1 $1^{- \text {Flag3x }}$ expression vector}

Fgfr1 isoform "c" corresponding to nucleotides 49-3774 of NM10206.3 was PCR-amplified from primary MEFs and TOPOcloned into the pCRII vector. Phusion polymerase was used to en- gineer a C-terminal triple-Flag (Flag3x) epitope tag and generate L423A, V429A, Y766F, and Y776F mutations, while the Y463F mutation was cloned directly from $F g f r 1^{C / C}$ MEFs. Each allele was then cloned into a mammalian expression vector under the control of the CAG promoter and bpA polyadenylation sequence. The proper sequence of each expression vector was confirmed by sequencing the full-length cDNA. Primers for each PCR step appear in Supplemental Table 3.

\section{Cell derivation and culture conditions}

FPCs were generated by dissecting the maxillary and nasal prominences of E11.5 embryos in PBS. The tissue was disassociated with $0.25 \%$ Trypsin-EDTA and cultured in DMEM with $10 \%$ calf serum, penicillin-streptomycin, and L-glutamine as previously described (Vasudevan and Soriano 2014). Each midface was seeded directly into three wells of a six-well dish and allowed to grow until subconfluence was achieved. All experiments were performed at passage 0 .

MEFs were generated from E13.5 embryos by removing the head and internal organs; the tissue was then minced and further disassociated in $0.25 \%$ Tripsin-EDTA and cultured in DMEM with $10 \%$ calf serum, penicillin-streptomycin, and Lglutamine.

3T3 cells stably expressing Fgfr $1^{- \text {Flag3x }}$ alleles were generated by cotransfecting linearized expression vector and neomycin resistance plasmid at a 1:3 molar ratio. Stable integrations were selected for by treating cells for $10 \mathrm{~d}$ in $0.5 \mathrm{mg} / \mathrm{mL}$ active G418 (Fischer Scientific, BP673-5). Clones were picked, expanded, and screened for comparable expression levels between alleles by immunoblot. Cells were cultured in DMEM with $10 \%$ calf serum with $0.5 \mathrm{mg} / \mathrm{mL}$ active G418, penicillin-streptomycin, and Lglutamine.

\section{Coimmunoprecipitation and Western blotting}

Stable 3 T3 cells expressing Fgfr $1^{\text {-Flag3x }}$ were serum-starved overnight, stimulated for $10 \mathrm{~min}$ with $50 \mathrm{ng} / \mathrm{mL}$ FGF1 and $5 \mu \mathrm{g} / \mathrm{mL}$ heparin, and lysed in NP-40 lysis buffer $(20 \mathrm{mM}$ Tris HCL at $\mathrm{pH}$ $8,137 \mathrm{mM} \mathrm{NaCl}, 10 \%$ glycerol, $1 \%$ Nonidet [NP-40], $2 \mathrm{mM}$ EDTA, $25 \mathrm{mM} \beta$ glycerol phosphate, $1 \mathrm{mM} \mathrm{Na}_{3} \mathrm{VO}_{4}, 10 \mathrm{mM}$ $\mathrm{NaF}, 1 \times$ protease inhibitor [Roche, 11836153001]). Western blots were developed using horseradish peroxidase-conjugated secondary antibodies, and film or Bio-Rad ChemiDoc MP imaging System was performed with Image Lab version 5.1 software. Quantification was performed using ImageJ software (version $1.47 \mathrm{t}$, National Institutes of Health). Graphs and statistical analysis were generated using Prism 6.0 software (GraphPad, Inc.).

\section{Skeletal preparations}

E18.5 or P0 pups were skinned, eviscerated, fixed in 95\% ethanol overnight, and stained $(0.015 \%$ Alcian blue, $0.005 \%$ Alizarin red, $5 \%$ glacial acetic acid, in $70 \%$ ethanol) overnight at $37^{\circ} \mathrm{C}$. Skeletons were then cleared in $1 \% \mathrm{KOH}$ and transferred to decreasing concentrations of $\mathrm{KOH}$ in increasing concentrations of glycerol.

\section{Antibodies}

The following antibodies were used: Cdx2 (Biogenex, MU392AUC), CrkL (Santa Cruz Biotechnology, sc-319), Erk1/2 (Cell Signaling, 9102L), Flag2 M2 (Sigma, F1804), Frs2 (H-91; Santa Cruz Biotechnology, sc-8318), Gata4 C-20 (Santa Cruz Biotechnology, sc-1237), Lamin B M20 (Santa Cruz Biotechnology, sc-6217), Nanog (Reprocell, RCAB0002P-F), pAkt (Ser473) (Cell Signaling, 
9271), pAkt (Thr308) 244F9 (Cell Signaling, 4056), pErk1/2 (T202/ Y2014) (Cell Signaling, 9101), pFrs2 (Tyr196) (Cell Signaling, 3864), pInk (T183/Y185) (Cell Signaling, 4671S), Plc 11 (Cell Signaling, 2822), pp38 (T180/Y182) 28B10 (Cell Signaling, 9216), pPlc $\gamma 1$ (Y783) (Cell Signaling, 2821), Stat3a (Cell Signaling, 8768), and pStat5 (Y694) D4739 (Cell Signaling, 4322). The anti$\beta$-tubulin E7 antibody developed by M. Klymkowsky was obtained from the Developmental Studies Hybridoma Bank developed under the auspices of the National Institute of Child Health and Human Development and maintained by Department of Biology at The University of Iowa.

\section{Physiology panels}

Control and mutant males of 6 and 14 wk of age were anesthetized with Avertin, and blood was collected using a terminal cardiac puncture. Blood samples were split into serum chemistries and complete blood cell count and shipped to Phoenix Central Laboratories (http://www.pclv.net) for analysis. Statistics were analyzed using Prism 6.0 (GraphPad, Inc.).

\section{$R T-q P C R$}

Embryos were dissected in PBS. For E7.5 embryos, a small portion of the extraembryonic ectoderm was taken for genotyping. For E8.5 embryos, a portion of the yolk sac was used for genotyping. Individual embryos were lysed, and mRNA was extracted according to Qiagen RNeasy kit standard protocol. cDNA was synthesized using a 2:1 ratio of random primers to Oligo(dT) with SuperScript II RT (Invitrogen). qPCR was performed with PerfeCTa SYBR Green FastMix for iQ (Quanta Biosciences) with Bio-Rad iQ5 multicolor real-time PCR detection system and analyzed with Bio-Rad iQ5 optical system software (version 2.0). Cycling conditions were as follows: step $1,3 \mathrm{~min}$ at $95^{\circ} \mathrm{C}$; step 2, $10 \mathrm{sec}$ at $95^{\circ} \mathrm{C}$; step $3,30 \mathrm{sec}$ at $60^{\circ} \mathrm{C}$; and repeat steps 2 and 3 for 40 cycles. Proper amplification was confirmed using a melting curve and by running samples on a gel to ensure that the correct size band was obtained. Primers appear in Supplemental Table 3. Graphs were made using Prism (GraphPad, Inc.).

\section{Acknowledgments}

We thank Tony Chen for expert assistance with genotyping, and our laboratory colleagues and Robert Krauss for helpful discussions and comments on the manuscript. We are grateful to Gareth John of the Icahn School of Medicine at Mount Sinai for providing the Stat $3^{\text {tm2aki }}$ mice. This work was supported by National Institutes of Health/National Institute of Dental and Craniofacial Research grant RO1 DE022778 and New York State Stem Cell Science grant IIRP N11G-131 to P.S. J.R.B. was supported by National Institutes of Health/National Institute of Dental and Craniofacial Research fellowship F31 DE023686.

\section{References}

Agosti V, Corbacioglu S, Ehler I, Waskow C, Somer G, Berrozpe G, Kissel H, Tucker CM, Manova K, Moore MA, et al. 2004. Critical role for Kit-mediated Src kinase but not PI 3-kinase signaling in pro T and pro B cell development. I Exp Med 199: 867-878.

Arman E, Haffner-Krausz R, Chen Y, Heath JK, Lonai P. 1998. Targetd disruption of fibroblast growth factor (FGF) receptor 2 suggests a role for FGF signaling in pregastrulation mammalian development. Proc Natl Acad Sci 95: 5082-5087.
Beenken A, Mohammadi M. 2009. The FGF family: biology, pathophysiology and therapy. Nat Rev Drug Discov 8: 235-253.

Blume-Jensen P, Jiang G, Hyman R, Lee K-F, O'Gorman S, Hunter T. 2000. Kit/stem cell factor receptor-induced activation of phosphatidylinositol $3^{\prime}$-kinase is essential for male fertility. Nat Genet 24: 157-162.

Browaeys-Poly E, Blanquart C, Perdereau D, Antoine A, Goenaga D, Luzy J, Garbay C, Issad T, Cailliau K, Burnol A. 2010. Grb14 inhibits FGF receptor signaling through the regulation of PLC $\gamma$ recruitment and activation. FEBS Lett 584: 4383-4388.

Calvert JA, Dedos SG, Hawker K, Flemming M, Lewis MA, Steel KP. 2011. A missense mutation in Fgfrl causes ear and skull defects in hush puppy mice. Mamm Genome 22: 290-305.

Chazaud C, Yamanaka Y, Pawson T, Rossant J. 2006. Early lineage segregation between epiblast and primitive endoderm in mouse blastocysts through the Grb2-MAPK pathway. Dev Cell 10: 615-624.

Cheng AM, Saxton TM, Sakai R, Kulkarni S, Mbamalu G, Vogel W, Tortorice CG, Cardiff RD, Cross JC, Muller WJ, et al. 1998. Mammalian Grb2 regulates multiple steps in embryonic development and malignant transformation. Cell 95: 793-803.

Ciruna B, Rossant J. 2001. Fgf signaling regulates mesoderm cell fate specification and morphogenetic movement at the primitive streak. Dev Cell 1: 37-49.

Ciruna B, Schwartz L, Harpal K, Yamaguchi TP, Rossant J. 1997. Chimeric analysis of fibroblast growth factor receptor-1 (Fgfr1) function: a role for FGFR1 in morphogenic movement through the primitive streak. Development 124: 2829-2841.

Danielian PS, Muccino D, Rowitch DH, Michael SK, McMahon AP. 1998. Modification of gene activity in mouse embryos in utero by tamoxifen-inducible form of Cre recombinase. Curr Biol 8: 1323-1326.

Deng C, Wynshaw-Boris A, Shen MM, Daugherty C, Ornitz DM, Leder P. 1994. Murine FGFR-1 is required for early postimplantation growth and axial organization. Genes Dev 8: 3045-3057.

Dhalluin C, Yan K, Plotnikova O, Lee K, Zeng L, Kuti M, Mujtaba S, Goldfarb M, Zhou M-M. 2000. Structural basis of SNT PTB domain interactions with distinct neurotrophic receptors $M o l$ Cell 6: 921-929.

Dorey K, Amaya E. 2010. FGF signalling: diverse roles during early vertebrate embryogenesis. Development 137: 3731-3742.

Dudka AA, Sweet SMM, Heath JK. 2010. Signal transducers and activators of transcription- 3 binding to the fibroblast growth factor receptor is activated by receptor amplification. Cancer Res 70: 3391-3401.

Eswarakumar V, Lax I, Schlessinger J. 2005. Cellular signaling by fibroblast growth factor receptors. Cytokine Growth Factor Rev 16: 139-149.

Feldman B, Poueymirou W, Papaioannou VE, DeChiara TM, Goldfarb M. 1995. Requirement of FGF-4 for postimplantation mouse development. Science 267: 246-249.

Francavilla C, Rigbolt KT, Emdal KB, Carraro G, Vemet E, Bekker-Jensen DB, Streicher W, Wikstrom M, Sundstrom M, Bellusci S, et al. 2013. Functional proteomics defines the molecular switch underlying FGF receptor trafficking and cellular outputs. Mol Cell 51: 707-722.

Frankenberg S, Gerbe F, Bessonnard S, Belville C, Pouchin P, Bardot O, Chazaud C. 2011. Primitive endoderm differentiates via a three-step mechanism involving Nanog and RTK signaling. Dev Cell 21: 1005-1013.

Goldin SN, Papaioannou VE. 2003. Paracrine action of FGF4 during periimplantation development maintains trophectoderm and primitive endoderm. Genesis 36: 40-47. 
Gotoh N, Laks S, Nakashima M, Lax I, Schlessinger J. 2004a. Frs2 family docking proteins with overlapping roles in activation of Map kinase have distinct spatial-temporal patterns of expression of their transcripts. FEBS Lett 564: 14-18.

Gotoh N, Manova K, Tanaka S, Murohashi M, Hadari Y, Lee A, Hamada Y, Hiroe T, Ito M, Kurihara T, et al. 2004b. The docking protein Frs2a is an essential component of multiple fibroblast growth factor responses during early mouse development. Mol Cell Biol 25: 4105-4116.

Guris DL, Fantes J, Tara D, Druker BJ, Imamoto A. 2001. Mice lacking the homologue of the human $22 \mathrm{q} 11.2$ gene CRKL phenocopy neurocristopathies of DiGeorge Syndrome. Nat Genet 27: 293-298.

Hadari YR, Gotoh N, Kouhara H, Lax I, Schlessinger J. 2001. Critical role for docking-protein Frs2a in FGF receptor-mediated signal transduction pathways. Proc Natl Acad Sci 98: 8578-8583.

Hamilton WB, Kaji K, Kunath T. 2013. Erk2 supresses self-renewal capacity of embryonic stem cells, but is not required for multi-lineage commitment. PLos One 8: e60907.

Hatano N, Mori Y, Oh-hora M, Kosugi A, Fujikawa T, Nakai N, Niwa H, Miyazaki J, Hamaoka T, Ogata M. 2003. Essential role for ERK2 mitogen-activated protein kinase in placental development. Genes Cells 8: 847-856.

Hinsby AM, Olsen JV, Bennett KL, Mann M. 2003. Signaling initiated by overexpression of the fibroblast growth factor receptor- 1 investigated by mass spectroscopy. Mol Cell Proteomics 2: 29-36.

Hoch R, Soriano P. 2006. Context-specific requirements for Fgfr1 signaling through Frs2 and Frs3 mouse development. Development 133: 663-673.

Huang J, Mohammadi M, Rodriguez GA, Schlessinger J. 1995. Reduced activation of Raf-1 and MAP kinase by a fibroblast growth factor receptor mutant deficient in stimulation of phosphatidylinositol hydrolysis. J Biol Chem 270: 5065-5072.

Kang M, Piliszek A, Artus J, Hadjantonakis A-K. 2013. FGF4 is required for lineage restriction and salt-and-pepper distribution of primitive endoderm factors but not their initial expression in the mouse. Development 140: 267-279.

Klinghoffer RA, Hamilton TG, Hoch R, Soriano P. 2002. An allelic series at PDGFaR locus indicates unequal contributions of distinct signaling pathways during development. Dev Cell 2: 103-113.

Kouhara H, Hadari Y, Spivak-Kroizman T, Schilling J, Bar-Sagi D, Lax I, Schlessinger J. 1997. A lipid-anchored Grb2-binding protein that links FGF-receptor activation to the Ras/MAPK signaling pathway. Cell 89: 693-702.

Kunath T, Saba-El-Leil M, Almousailleakh M, Wray J, Meloche S, Smith A. 2007. FGF stimulation of the ERK1/2 signalling cascade triggers transition of pluripotent embryonic stem cells from self-renewal to lineage commitment. Development 134: 2895-2902.

Lanner F, Rossant J. 2010. The role of FGF/Erk signaling in pluripotent cells. Development 137: 3351-3360.

Larsson H, Klint P, Landgren E, Claesson-Welsh L. 1999. Fibroblasts growth factor receptor-1-mediated endothelial cell proliferation is dependent on the Src homology $(\mathrm{SH}) 2 / \mathrm{SH} 3$ domain-containing adaptor protein Crk. I Biol Chem 274: 25726-25734.

Maina F, Pante G, Helmbacher F, Porthin A, Davies AM, Carola P, Klein R. 2001. Coupling Met to specific pathways results in distinct developmental outcomes. Mol Cell 7: 1293-1306.

McDougall K, Kubu C, Verdi JM, Meakin SO. 2001. Developmental expression patterns of the signaling adaptors FRS-2 and FRS-3 during early embryogenesis. Mech Dev 103: 145-148.
Mohammadi M, Honegger AM, Rotin D, Fischer R, Bellot F, Li W, Dionne CA, Jaye M, Rubinstein M, Schlessinger J. 1991. A tyrosine-phosphorylated carboxy-terminal peptide of the fibroblast growth factor receptor (flg) is a binding site for the $\mathrm{SH} 2$ domain of phospholipase C- $\gamma 1$. Mol Cell Biol 11: 5068-5078.

Mohammadi M, Dionne C, Li W, Li N, Spivak T, Honegger A, Jaye M, Schlessinger J. 1992. Point mutation in FGF receptor eliminates phosphosphatidylinositol hydrolysis without affecting mitogenesis. Nature 358: 681-684.

Moon AM, Guris DL, Seo J-h, Li L, Hammond J, Talbot A, Imamoto A. 2006. Crkl deficiency disrupts fgf8 signaling in a mouse model of 22q11 deletion syndromes. Dev Cell 10: 71-80.

Morris SA, Graham SJ, Jedrusik A, Zernica-Goetz M. 2013. The differential response to Fgf signalling in cells internalized at different times influences lineage segregation in preimplantation mouse embryos. Open Biol 3: 130104.

Nichols J, Silva J, Roode M, Smith A. 2009. Suppression of Erk signalling promotes ground state pluripotency in the mouse embryo. Development 136: 3215-3222.

Nutt S, Dingwell K, Holt C, Amaya E. 2001. Xenopus Sprouty2 inhibits FGF-mediated gastrulation movements but does not affect mesoderm induction and paterning. Genes Dev 15: $1152-1166$.

Ohnishi Y, Huber W, Tsumura A, Kang M, Xenopolous P, Kurimoto K, Oles AK, Zrauzo-Bravo MJ, Saitou M, Hadjantonakis A-K, et al. 2013. Cell-to-cell expression variability followed by signal reinforcement progressively segregates early mouse lineages. Nat Cell Biol 16: 27-37.

Ong SH, Guy GR, Hadari YR, Laks S, Gotoh N, Schlessinger J, Lax I. 2000. Frs2 proteins recruit intracellular signaling pathways by binding to diverse targets on fibroblast growth factor and nerve growth factor receptors. Mol Cell Biol 20: 979-989.

Ong SH, Hadari Y, Gotoh N, Guy GR, Schlessinger J, Lax I. 2001. Stimulation of phosphatidylinositol 3-kinase by fibroblast growth factor receptors is mediated by coordinated requirement of multiple docking proteins. Proc Natl Acad Sci 98: 6074-6079.

Ornitz DM, Itoh N. 2015. The fibroblast growth factor signaling pathway. Wiley Interdiscip Rev Dev Biol 4: 215-266.

Partanen J, Schwartz L, Rossant J. 1998. Opposite phenotypes of hypomorphic and $\mathrm{Y} 766$ phosphorylation site mutations reveal a function for Fgfr1 in anteroposterior patterning of mouse embryo. Genes Dev 12: 2332-2344.

Reilly JF, Mickey G, Maher PA. 2000. Association of fibroblast growth factor receptor 1 with the adaptor protein Grb14. I Biol Chem 275: 7771-7778.

Saba-El-Leil MK, Vella FD, Vernay B, Voisin L, Chen L, Labrecque N, Ang S-L, Meloche S. 2003. An essential function of the mitogen-activated protein kinase Erk2 in mouse trophoblast development. EMBO Rep 4: 964-968.

Sandell LL, Kurosaka H, Trainor PA. 2012. Whole mount nuclear fluorescent imaging: convenient documentation of embryo morphology. Genesis 50: 844-850.

Schmahl J, Raymond C, Soriano P. 2007. PDGF signaling specificity is mediated through multiple immediate early genes. Nat Genet 39: 52-60.

Sivak J, Petersen L, Amaya E. 2005. FGF Signal interpretation is directed by sprouty and spred proteins during mesoderm formation. Dev Cell 8: 689-701.

Sorokin A, Mohammadi M, Huang J, Schlessinger J. 1994. Internalization of fibroblast growth factor receptor is inhibited by a point mutation at tyrosine 766. I Biol Chem 269: 1705617061. 
Stavridis MP, Lunn JS, Collins BJ, Storey KG. 2007. A discrete period of FGF-induced Erk1/2 signaling is required for vertebrate neural specification. Development 134: 2889-2894.

Takeda K, Kaisho T, Yoshida N, Takeda J, Kishimoto T, Akira S. 1998. Stat3 activation is responsible for IL-6-dependent T cell proliferation through preventing apoptosis: generation and characterization of $\mathrm{T}$ cell-specific Stat3-deficient mice. $J$ Immunol 161: 4652-4660.

Tallquist MD, Soriano P. 2000. Epiblast-restricted Cre expression in MORE mice: a tool to distinguish embryonic vs. extra-embryonic gene function. Genesis 26: 113-115.

Tallquist MD, French WJ, Soriano P. 2003. Additive effects of PDGF receptor $\beta$ signaling pathways in vascular smooth muscle cell development. PLoS Biol 1: 288-299.
Trokovic N, Trokovic R, Mai P, Partanen J. 2003. Fgfrl regulates patterning of the pharyngeal region. Genes Dev 17: 141-153.

Trokovic N, Trokovic R, Partanen J. 2005. Fibroblast growth factor signalling and regional specification of the pharyngeal ectoderm. Int I Dev Biol 49: 797-805.

Vasudevan HN, Soriano P. 2014. SRF Regulates craniofacial development through selective recruitment of MRTF cofactors by PDGF signaling. Dev Cell 31: 332-344.

Yamaguchi TP, Harpal K, Henkemeyer M, Rossant J. 1994. fgfr-1 is required for embryonic growth and mesodermal patterning during mouse gastrulation. Genes Dev 8: 3032-3044.

Yamanaka Y, Lanner F, Rossant J. 2010. FGF signal-dependent segregation of primitive endoderm and epiblast in the mouse blastocysts. Development 137: 715-724. 


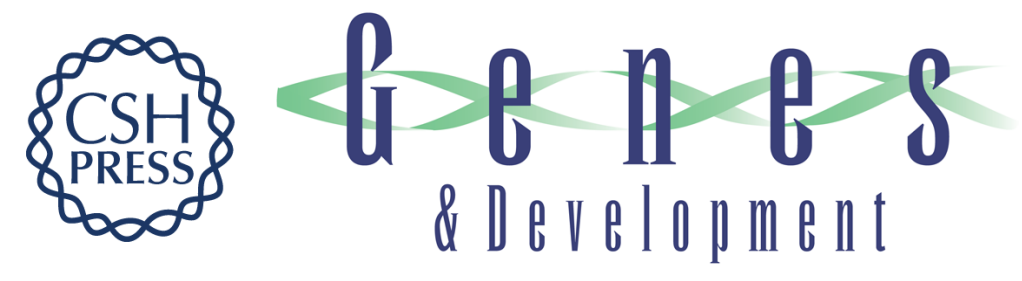

\section{Fgfr1 regulates development through the combinatorial use of signaling proteins}

J. Richard Brewer, Andrei Molotkov, Pierre Mazot, et al.

Genes Dev. 2015, 29:

Access the most recent version at doi:10.1101/gad.264994.115

\section{Supplemental Material \\ http://genesdev.cshlp.org/content/suppl/2015/09/04/29.17.1863.DC1}

References

This article cites 63 articles, 29 of which can be accessed free at: http://genesdev.cshlp.org/content/29/17/1863.full.html\#ref-list-1

Creative This article is distributed exclusively by Cold Spring Harbor Laboratory Press for the first Commons License

Email Alerting Service six months after the full-issue publication date (see http://genesdev.cshlp.org/site/misc/terms.xhtml). After six months, it is available under a Creative Commons License (Attribution-NonCommercial 4.0 International), as described at http://creativecommons.org/licenses/by-nc/4.0/.

Receive free email alerts when new articles cite this article - sign up in the box at the top right corner of the article or click here.

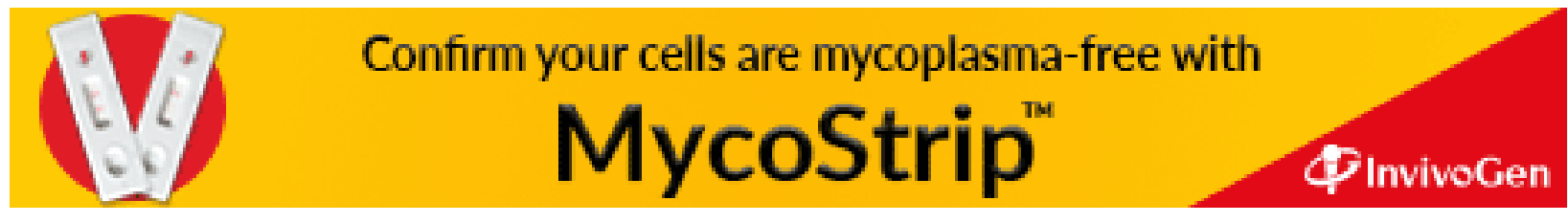

